\title{
International business and global value chains
}

DOI:

$10.4337 / 9781788113779$

\section{Document Version}

Final published version

Link to publication record in Manchester Research Explorer

\section{Citation for published version (APA):}

Sinkovics, N., \& Sinkovics, R. R. (2019). International business and global value chains: Handbook on global value chains. In S. Ponte, G. Gereffi, \& G. Raj-Reichert (Eds.), International business and global value chains (pp. 417431). Edward Elgar Publishing Ltd. https://doi.org/10.4337/9781788113779

\section{Published in:}

International business and global value chains

\section{Citing this paper}

Please note that where the full-text provided on Manchester Research Explorer is the Author Accepted Manuscript or Proof version this may differ from the final Published version. If citing, it is advised that you check and use the publisher's definitive version.

\section{General rights}

Copyright and moral rights for the publications made accessible in the Research Explorer are retained by the authors and/or other copyright owners and it is a condition of accessing publications that users recognise and abide by the legal requirements associated with these rights.

\section{Takedown policy}

If you believe that this document breaches copyright please refer to the University of Manchester's Takedown Procedures [http://man.ac.uk/04Y6Bo] or contact uml.scholarlycommunications@manchester.ac.uk providing relevant details, so we can investigate your claim.

\section{OPEN ACCESS}


Sinkovics, Noemi and Rudolf R. Sinkovics (2019), "International business and global value chains," in Handbook on global value chains, Stefano Ponte, Gary Gereffi, and Gale Raj-Reichert (Eds.). Cheltenham, UK: Edward Elgar, 417-431. https://doi.org/10.4337/9781788113779

\section{International business and global value chains Noemi Sinkovics and Rudolf R. Sinkovics}

\subsection{INTRODUCTION}

This chapter aims at providing an overview of the dynamics between multinational enterprises (MNEs) and global value chains (GVCs). In order to do so, we draw on the international business (IB) literature and compare and contrast it to the GVC literature. The common denominator between the two bodies of literature is the MNE and its perceived role in the global economy. Perhaps the best metaphor to depict the relationship between the two fields is that of cartography. Depending on the purpose of the map, a cartographer can use different scales and representations of the same geographical area. Conversely, a cartographer can zoom in on a particular part of that geographical area and develop a more detailed map than would be possible if one focused on the entire area. Additional factors that can make the comparison of maps challenging are the time of creation (topographies can change over time) and the sophistication of instruments/ technologies used in the mapping process.

To translate this metaphor to our endeavor, when attempting to draw a roadmap for a synthesis between the two bodies of literature, we need to take into consideration the different paradigms within each field along with the differences (or similarities) in theoretical foundations, object of inquiry, the temporal influence shaping each view, and the focal concepts. Table 26.1 provides such an overview of the main developments in both fields by drawing on Bair (2005) and Ponte, Sturgeon and Dallas (Chapter 6 this volume) for the GVC literature, and Forsgren (2017) for the IB literature. As can be seen from Table 26.1, the six theoretical perspectives on the MNE outlined by Forsgren (2017) not only capture the changing forms of the MNE within the IB literature but also allow us to zoom in on specific aspects of MNEs. In addition to the differences in theoretical foundations, Forsgren (2017) also identifies the different assumptions about the operating environment and the extent to which each view considers MNEs' contribution to the welfare of society.

While GVC analysis shares a firm-centric approach with the IB literature, it uses the concepts of governance and upgrading to analyze the organization of global industries. The holistic nature of the GVC analysis framework (Gereffi and Fernandez-Stark, 2016; see also Fernandez-Stark and Gereffi, Chapter 2 this volume) allows the researcher to use several entry points into the analysis. In general, the concept of governance represents a top-down analysis of how lead firms organize geographically dispersed economic activities. However, as Ponte and colleagues outline in Chapter 6 in this Handbook, there are three approaches to analyzing GVC governance: governance as driving, governance as linking, and governance as normalizing. Similarly to Forsgren's (2017) six perspectives on MNEs, the three governance approaches are also a product of their time. Table 26.1 summarizes their main dimensions. The concept of upgrading is a bottom-up view of how countries, regions, and firms gain access to GVCs or how they maintain or improve their positions in GVCs (Lee and Gereffi, 2015). 


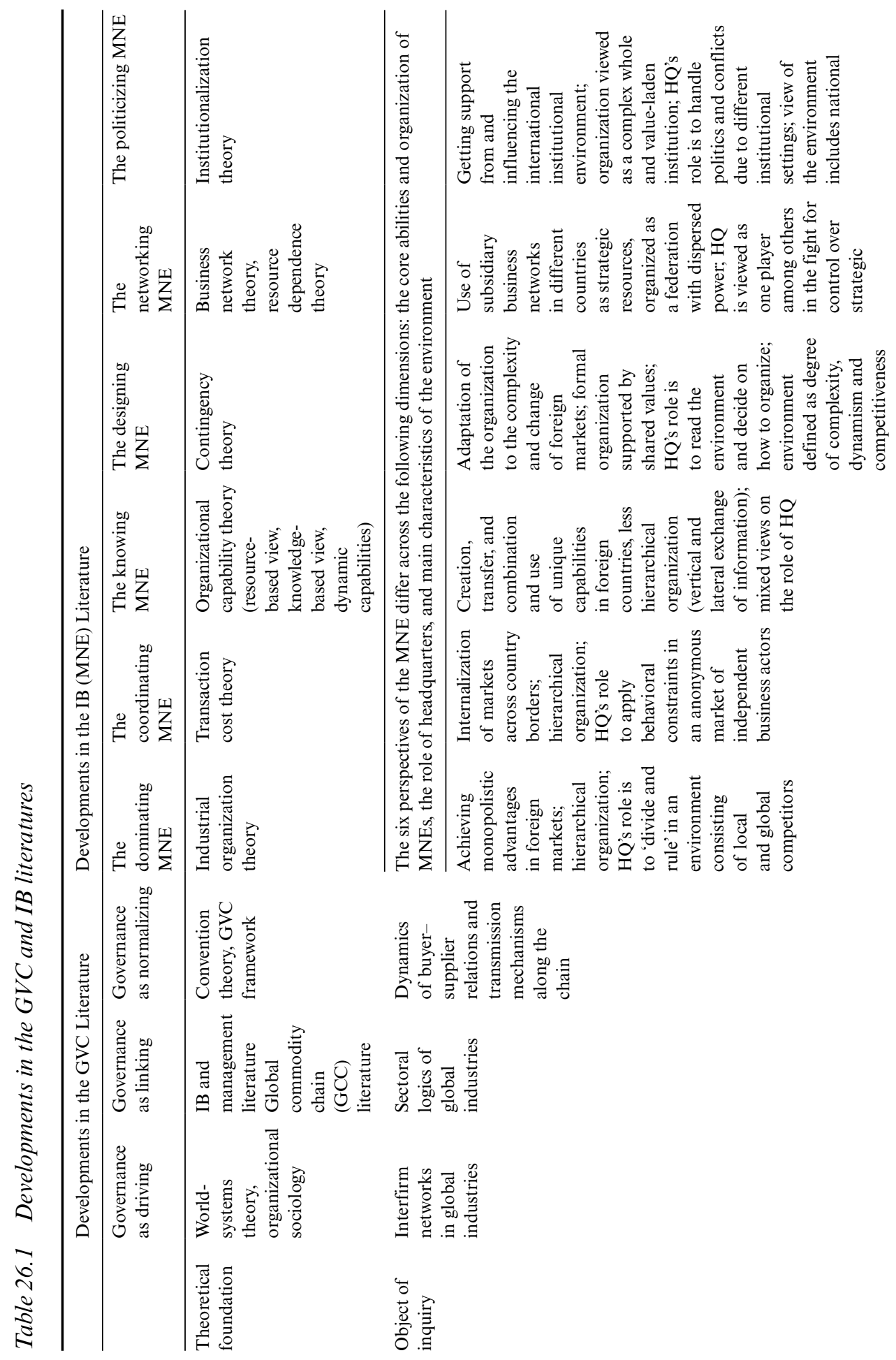




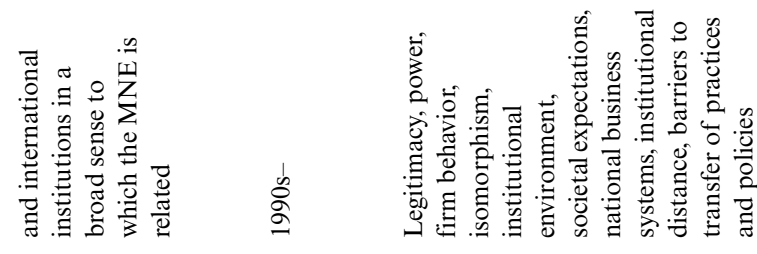

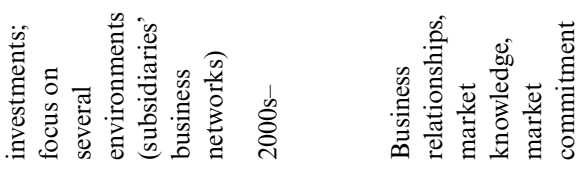

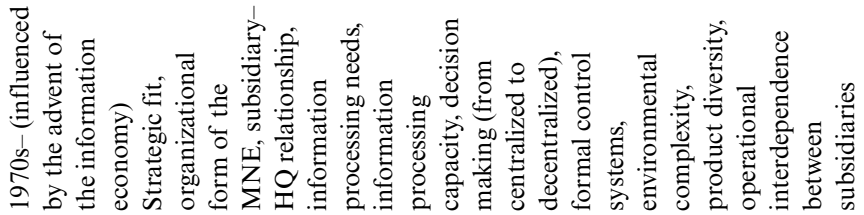

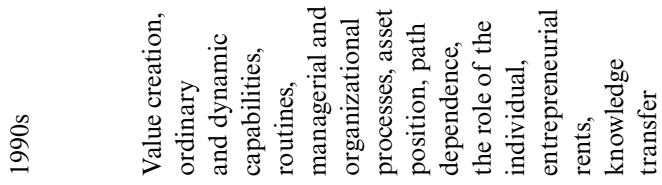

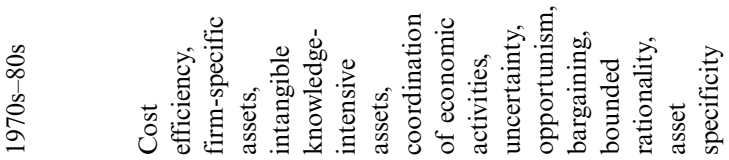

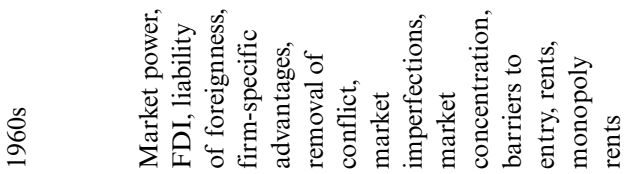

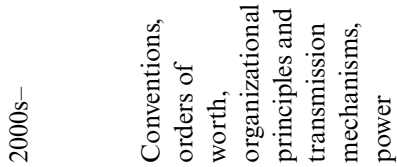

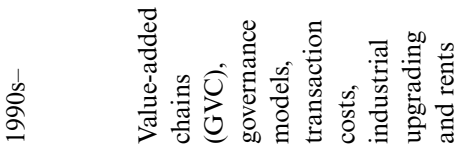

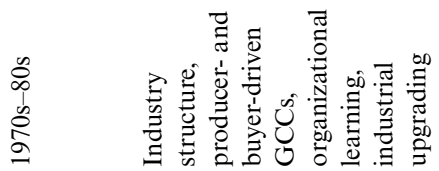

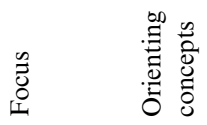




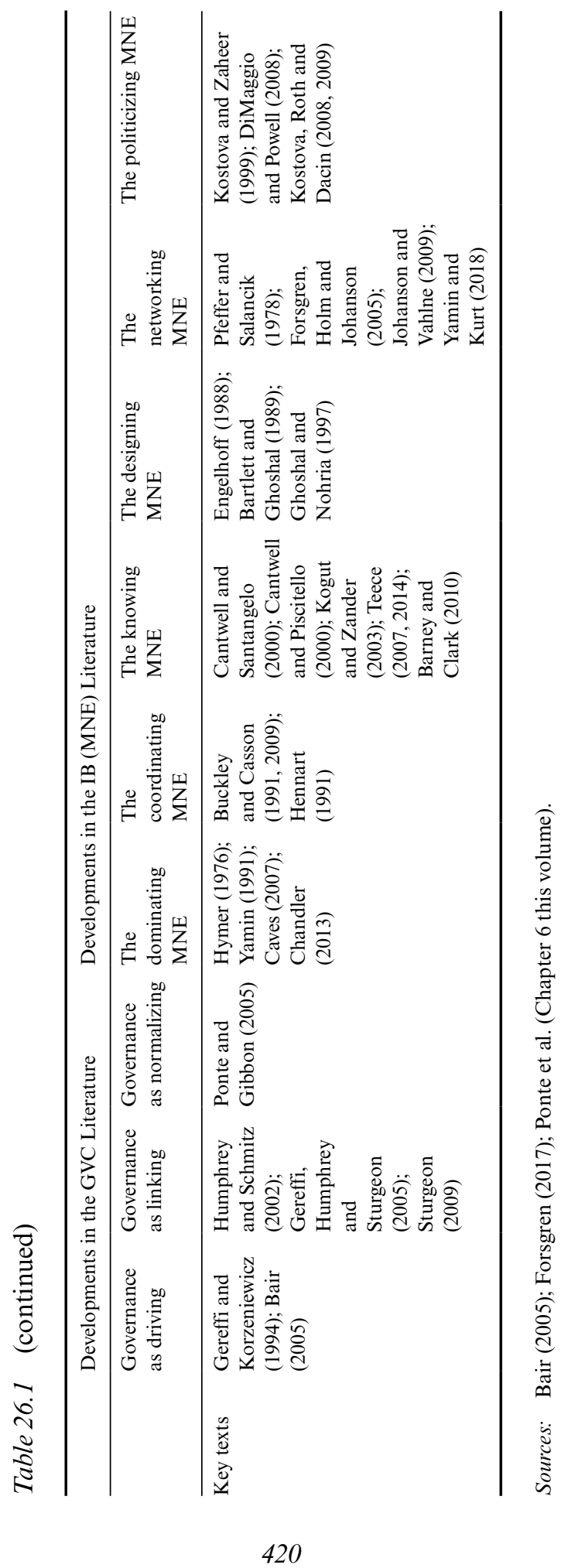


The rest of this chapter will investigate how each theoretical MNE perspective in IB relates to the concepts of governance and upgrading and what this means for the analysis of GVC dynamics. We do so by remaining conscious of how research fields develop over time. We also take into account shared intellectual influences, spillovers, and parallel developments. This is important because, despite the commonalities, the integration between the two literatures in terms of cross-referencing remains rather limited (Sinkovics et al., 2018b). This can be explained with how the boundaries around research fields develop. These boundaries reflect the knowledge, interests, and practices of researchers who actively contribute to a field and reference a common body of literature. ${ }^{1}$ Without this shared core body of literature that is generally recognized by the researchers within a specific field, no research tradition can survive (Pierce, 1990). As a consequence, even though the GVC literature can arguably be regarded as part of the same overarching research program as the MNE literature in IB (cf. Lakatos, 1978), based on the citation patterns they constitute two separate fields (Sinkovics et al., 2018b). Notwithstanding that, researchers from both fields recognize that, in order to push the boundaries of the overarching research program, there is need for more meaningful integration. Given the complementary lenses of the two fields, there is a lot that can be gained from such integration efforts (cf. De Marchi, Di Maria and Ponte, 2014; Giuliani and Macchi, 2014; Lee and Gereffi, 2015; Sinkovics et al., 2015).

\subsection{THE SIX TALES OF THE MNE AND THEIR IMPLICATIONS FOR GVCs}

In the third edition of his book Theories of the Multinational Firm, Forsgren (2017) outlines six theoretical perspectives, or 'tales,' that have emerged throughout the six decades of IB research. What is important to note is that these perspectives are complex and multidimensional and, while some of them were built on and evolved from an earlier perspective, others emerged out of disagreement with a specific view (Forsgren, 2017). As is the case with most scientific ideas, an exact delineation between them is not possible as they did not emerge in a vacuum (cf. Lakatos, 1978; Steiner, 1988). Furthermore, as we will also show in our discussions below, the GVC and IB literatures share some common intellectual influences (cf. Bair, 2005; Sturgeon, 2009). This is especially true for governance as the linking approach (Ponte et al., Chapter 6 this volume; Sturgeon, 2009). However, a quick citation analysis ${ }^{2}$ shows that after the take-off of the GVC agenda, the integration of core IB thinking decreased. In the following sections, we point GVC scholars to IB perspectives that can be useful for their overarching agenda. The first three views originate from economic theory. The other three are rooted in different types of organization theory.

\subsubsection{The Dominating MNE}

A child of the 1960s, the theory of the dominating MNE was the first theory on foreign direct investment (FDI) at the firm level. It is mostly based on the work of Stephen Hymer (Forsgren, 2017). Before that, the predominant unit of analysis was the country level (Buckley, 2002; Rugman, Verbeke and Nguyen, 2011). Hymer's work triggered a 
shift in focus from capital movements across borders to firms and their international operations (Hymer, 1976). The emphasis is on the firm-specific advantages that a national firm can leverage in foreign markets despite the liability of foreignness it faces in host countries. These firms are able to exploit market imperfections, to some extent through innovation, and achieve a superior market position. A further central concept, in addition to firm-specific advantages, is 'the removal of conflicts' among firms (Yamin, 1991), which includes but is not limited to cross-border mergers and acquisitions (M\&As), international cartels, and different kinds of strategic alliances mostly among competitors in home and/or host countries. In this perspective, the MNE is viewed as a hierarchy where the decision-making power rests with the headquarters (HQ). It is assumed that subsidiaries have little power in the organization, which is also reflected in the lower levels of remuneration they receive. The possibility of power retention by the HQ determines the extent of internationalization of the MNE (Forsgren, 2017). The theory of the dominating MNE offers an explanation of how and why MNEs in advanced economies developed and served as an inspiration for all modern thinking about MNEs (ibid.).

The influence of the dominating MNE is also present in the GVC literature. It is captured in the GVC governance framework under the hierarchical type of governance (cf. Gereffi et al., 2005). As Sako and Zylberberg (Chapter 21 this volume) point out, corporate agency should play a more important part in GVC research than it currently does. In the case of the dominating MNE, the HQ's desire to control the organization trumps the implementation of more rational choices. In other words, HQ will be less likely to outsource operations even if the complexity of transactions, the capability of the available suppliers, and the codifiability of knowledge would allow it. Instead, a dominating MNE will attempt to achieve vertical market power through M\&As and/or horizontal power through strategic alliances and cartels. Furthermore, the HQ's need to control and dominate both the industry it operates in and its internal organization leaves little room for upgrading in host countries.

\subsubsection{The Coordinating MNE}

The theory of the coordinating MNE developed in the 1970s and 1980s. It built on the assumption discussed in the theory of the dominating MNE that a monopolistic (or at least an oligopolistic) advantage is necessary in order to overcome the liability of foreignness (Forsgren, 2017). However, critics of the dominating MNE pointed to the lack of explanation of how firm-specific advantages are built (cf. Buckley and Casson, 1991). In response to this perceived shortcoming, the theory of the coordinating MNE focuses on the activities inside the MNE. Also called internalization theory, this perspective seeks to explain the choice of hierarchical (or nearly hierarchical) integration through analyzing the interdependent economic activities necessary to design, produce, and sell products. Its focus is on the development, exploitation, and control of knowledge-intensive assets. This theory is essentially an application of transaction cost economics to the MNE and states that MNEs internalize transactions that are difficult to handle between independent firms (Forsgren, 2017).

According to Buckley (2016, p. 77), internalization theory encompasses three approaches that can be nested within each other like 'Russian dolls.' The first approach is focused on the explanation of why MNEs exist, how they grow and strategize. The second approach, 
also known as the 'global factory,' explores how MNEs can maximize profits through the outsourcing of operations and the internalization of knowledge. The third approach, global systems, aims at predicting the optimal network configuration in terms of profit maximization by breaking down the global economy into firms, activities, boundaries, and locations and then calculating the cost of operations and flows between different locations. The global systems view encompasses the two previous approaches (Buckley, 2016; Buckley and Hashai, 2004). It needs to be emphasized, however, that the global factory (Buckley and Ghauri, 2004) is a specific application of internalization theory that took into consideration the impact of the changing landscape in the global economy compared to what theorists observed in the 1970s and early 1980s (cf. Buckley and Strange, 2015). While earlier applications mainly focused on offshoring without (or with only minimal) externalization (cf. Grunwald, Flamm and Brookings, 1985), later applications looked into retaining control over knowledge while externalizing operations that contribute to a reduction of location and transaction costs (Buckley and Strange, 2015).

The connection between the theory of the coordinating MNE and the GVC literature needs to be discussed against the two pillars of GVC analysis - governance and upgrading (cf. Lee and Gereffi, 2015). It is important to note that historically the global factory was an advanced economy phenomenon. Its development is shaped by the nature of home-country institutional and factor market characteristics (cf. Bilgili, Kedia and Bilgili, 2016; Buckley and Strange, 2015; Hoskisson et al., 2013). Global factories in developing economies are less prevalent for a number of reasons, including the lack of adequate entrepreneurial and strategic abilities, limited access to strong finance, weak education systems that make the cultivation of skilled personnel difficult, and the power of existing foreign global factories dampening the development of local suppliers (Buckley, 2009). From a bottom-up (upgrading) perspective, the development of a global factory can be seen as the highest form of upgrading in developing countries on their journey towards becoming more advanced economies (Buckley, 2009; Buckley and Strange, 2015). From a top-down perspective (governance), the GVC framework can help explain the changes in the governance of global factories over time (cf. Buckley and Strange, 2015).

\subsubsection{The Knowing MNE}

Although scholars building on internalization theory go into more detail about firmspecific advantages, their analysis is limited to uncertainty, bounded rationality, bargaining, and opportunism (Forsgren, 2017). The knowing MNE perspective emphasizes the unique nature of capabilities in individual MNEs. These capabilities are seen as inseparable from the individual firm as they are linked to its routines and organizational principles. This is in contrast to how firm-specific assets are regarded by the previous two theories - that in principle it is possible, though very costly, to trade firm-specific assets. The knowing MNE perspective defines the essence of the MNE as its ability to build, transfer, combine, and utilize unique capabilities in host countries. The replication of capabilities within the MNE (across subsidiaries) and beyond is influenced by factors such as geographic and cultural distance, differences in business logics, and the difficulty to separate capabilities from the context they emerged from (ibid.).

Furthermore, this view also builds on the assumption that fixed assets such as plants and readily purchasable equipment do not constitute the main source of firm-specific 
advantage - knowledge embedded in individuals does (ibid.). As a consequence, when it comes to knowledge transfer, this theoretical perspective assumes that it is easier to transfer tacit, not easily codifiable knowledge within the boundaries of the organization (between subunits) than between a subunit and an external organization. This is because the identities of individuals within the boundaries of the organization have more in common than the identities of individuals outside the boundaries of the organization. This manifests as familiarity with the goals, strategies, and culture of the firm, as well as the nature of the information channels and routines within the organization (ibid.; Kogut and Zander, 1996, 2003). Another school of thought within the knowing MNE emphasizes the importance of the impact of the subsidiary's environment on the nature of capability development. This view explores how MNEs accumulate technological competence through the engagement of subunits with local actors (Cantwell and Piscitello, 2000, 2015; Cantwell and Zhang, 2011).

While at face value the knowing MNE perspective is mostly inward oriented - that is, how to build, exploit, and transfer capabilities within the boundaries of the MNE - the insights from this body of literature can benefit GVC studies in various ways. The relational type of governance in the GVC governance framework is explained by Ponte et al., Chapter 6 in this book, as linkages 'where tacit information is exchanged between buyers and suppliers with unique or at least difficult-to-replicate capabilities, governed by trust and reputation.' The literature within the knowing MNE paradigm can help GVC research to further explore effective knowledge management and knowledge transfer mechanisms (Ambos and Ambos, 2009; Ambos, Nell and Pedersen, 2013; Andersson et al., 2015; Argote and Ingram, 2000; Levin and Cross, 2004; Tran, Mahnke and Ambos, 2010).

The knowing MNE furthermore acknowledges that while routines, administrative systems, and other organizational processes are important, individuals play a crucial role, as knowledge cannot be developed or leveraged without the agency of individual employees (Forsgren, 2017; Foss, 2009). To this end, using a microfoundations lens can contribute to GVC work focusing on firm-internal processes of disarticulation and counteraction (cf. Choksy, Sinkovics and Sinkovics, 2017; Ponte et al., Chapter 6 this volume; Raj-Reichert, Chapter 22 this volume). A microfoundations approach is well suited to investigate how capabilities emerge from individual actions and interactions in both MNEs and suppliers and what managers can do to create or change capabilities (Felin and Foss, 2005; Foss, 2009; Hoque, Sinkovics, and Sinkovics, 2016; Sinkovics, Hoque and Sinkovics, 2018a). This is because it aims at achieving an understanding of how individual-level factors influence organizations, how the interactions of individuals contribute to organization level outcomes, and how macro-level variables are mediated by micro-level actions and interactions (Abell, Felin and Foss, 2008; Felin, Foss and Ployhart, 2015).

\subsubsection{The Designing MNE}

In the last three perspectives, the role of the operating environment was only considered to a limited extent. In contrast, the theory of the designing MNE builds on contingency theory and makes the role of the environment in the firm's strategic action more explicit. It holds that: '1) there is no one best way to organize a firm; 2) not all ways of organizing a firm are equally effective; 3 ) the best way to organize a firm depends on the nature of the 
environment to which the organization must relate' (Forsgren, 2017, p. 79). The designing MNE perspective thus focuses on the diversity of existing organizational forms and tasks and holds that depending on the characteristics of the environment and the nature of the task some organizational forms generate better performance outcomes than others. In other words, the emphasis is on achieving a strategic fit between the organization and the environment. This requires the MNE to adapt to its many environments through its organizational design.

Similarly to the previous theoretical perspectives, there are several schools of thought that developed under the umbrella of the designing MNE over time. Bartlett and Ghoshal (1989) outline different organizational models depending on the degree of standardization and/or adaptation required across the markets in which the MNE operates: international, multinational, global, and transnational modes of organization. The transnational model encompasses a structure that can handle local responsiveness and flexibility as well as global coordination and economies of scale. To achieve this, subsidiaries are autonomous to a certain degree, yet well integrated in a worldwide operation (Forsgren, 2017).

Engelhoff's (1988) information processing view assumes that there is always a discrepancy between the information processing needs of the organization and its capacity to process that information. The central concepts contributing to whether decision making is centralized or decentralized are operational interdependence between subsidiaries and change at the subsidiary level, and environmental complexity and size at the company level (Forsgren, 2017). Ghoshal and Nohria's (1997) differentiated network view of the MNE zooms in on differences at the subsidiary level to an ever-greater extent. This school of thought holds that the structure of the MNE 'can be understood as distributed resources linked through different types of relations: "1) "local" linkages within each national subsidiary; 2) linkages between the headquarters and the subsidiaries; and 3) linkages between the subsidiaries themselves' (Forsgren, 2017, p. 92). Ghoshal and Nohria (1997) thus acknowledge the complexity and heterogeneity within MNEs. They perform a more nuanced analysis of subsidiaries' environment as well as of organizational design factors. While there are parallels with Engelhoff's (1988) perspective, Ghoshal and Nohria (1997) also consider whether and to what extent subsidiaries share certain values with the parent organization (Forsgren, 2017).

The designing MNE paradigm has implications for GVC governance as linking and governance as normalizing (Ponte et al., Chapter 6 this volume). As noted by Yeung and Coe (2015), how an MNE is internally structured and how this structure changes over time affects interfirm coordination and control and the development implications thereof. More specifically, GVC scholars could look into how GVC dynamics change over time depending on the degree of centralization/decentralization in the lead firm. As an example, Lorenzen and Mudambi (2013) investigate the impact of different MNE network structures on the catch-up trajectory (upgrading) of two developing country clusters - Bollywood and Bangalore. Furthermore, contingency theory can also make a useful contribution to understanding the conditions under which social upgrading occurs. There is growing empirical evidence for the inefficiencies of private governance (cf. Locke, 2013). Especially when it comes to corporate social responsibility (CSR) and labor standards, MNEs often adopt a 'one-size-fits-all' approach (e.g., Lucea and Doh, 2012; Sinkovics and Hoque, 2018). To better understand the occurrence of social upgrading, GVC scholars could also analyze what the most optimal MNE structure looks like 
that allows the design of codes, policies, and standards in ways that can balance local responsiveness and flexibility, and global coordination and economies of scale.

\subsubsection{The Networking MNE}

The perspective of the networking multinational disaggregates the MNE into its parts and treats each subsidiary as a unique entity. As such, the focus shifts to conflicting interests and power struggles between the individual subsidiaries as well as to their embeddedness through their relationships with other entities outside the MNE boundary such as consumers, suppliers, subcontractors, competitors, and research partners. The emphasis here is on the heterogeneous character of the MNE. The individuality of each subsidiary is more pronounced in the networking MNE paradigm than in the designing MNE. The extent of connection between subsidiaries depends on the degree to which they share business networks rather than on the degree of their integration into the MNE's overarching administrative, structural, and legal organization (Forsgren, 2017). The underlying framework is provided by business network theory, which places relationships that are important for the long-term well-being of the business at the center of analysis. This theory assumes that a firm must be an insider to a given network in order to fully understand it and the role it can play within it (ibid.).

Central analytical concepts include market knowledge and market commitment. Market knowledge is obtained through exchange with business partners and pertains to knowledge about these partners' capabilities. Market commitment relates to the commitment to particular business relationships in a business network. This perspective zooms in on the investment of time and resources in business relationships, which in turn provides managers with information that helps them to evaluate opportunities. The active search for opportunities motivates: (1) the development of business relationships; (2) the decision to coordinate activities across relationships instead of keeping it within the boundaries of the firm (also see Sako and Zylberberg, Chapter 21 this volume); and (3) the attempt to generalize the learning arising from specific relationships to other relationships (Forsgren et al., 2005).

The connection between the networking MNE and GVC research lies in both perspectives' interest in interfirm relationships that go beyond the boundaries of the MNE. However, the networking MNE calls for a more nuanced analysis of GVC governance. This is because each subsidiary is treated as an individual business actor with its own business network (Forsgren, 2017). As a consequence, from an analytical perspective, individual subsidiaries of a given MNE can be treated as 'lead firms' of individual value chains. Thus, it is conceivable that in two value chains, two different subsidiaries of the same MNE may not be connected to each other. Conversely, it is also conceivable that two individual subsidiaries of the same MNE develop different relationships with suppliers in the same value chain. This implies that strategic decisions regarding the nature of interfirm relationships are not only determined by rational, economic factors (cf. Sako and Zylberberg, Chapter 21 this volume).

To this end, the analysis of interfirm relationships can be opened up to the investigation of the motivation of individuals and/or groups of individuals occupying different network positions (cf. Foss, 2009). This is important because individuals in organizations differ in terms of their motivation to share knowledge (ibid.), drive change or contribute to the 
tackling of grand challenges (cf. Buckley, Doh and Benischke, 2017). As a consequence, a better understanding of the motivations of different individuals in different positions across the different entities within the MNE is needed to better understand supplier upgrading (social or economic or both) in GVCs.

For example, by analyzing the ethical foundations of strategic decision making in four Bangladeshi garment manufacturers and their MNE buyers, Sinkovics and Hoque (2018) show how different ethical principles shape the design, implementation, and outcomes of CSR/labor standards and codes and ultimately social upgrading. Furthermore, managers' comfort zone with regard to the associated risk and uncertainty (Jensen and Petersen, 2013), as well as other 'hassle factors' (Schotter and Beamish, 2013), also play an important role in the development of interfirm relationships. In other words, GVC research could use the insights from the networking MNE paradigm to identify additional factors that shape GVC governance, in addition to the complexity of transactions, the codifiability of knowledge, and the capability of the supplier.

\subsubsection{The Politicizing MNE}

The politicizing multinational perspective advocates the analysis of each MNE as a unique case. The focus is on the MNE as a political actor that adapts to the goals of internal groups and the values of the societies it operates in. This view goes beyond the business environment and includes a range of other actors including governments, civil society organizations, as well as the general public. The MNE is seen as adapting to, and at the same time influencing, its environments. Understanding the different interests and power structures between individual actors (e.g., headquarters, subsidiaries, governments, non-governmental organizations, suppliers, etc.) can shed light on the extent to which the MNE can influence local contexts. The politicizing MNE perspective emphasizes the importance of individual countries in the equation and the significance of building legitimacy in a given host country. Furthermore, this view of the MNE also looks into how institutional environment differences between countries create challenges for the transfer of practices and policies (Forsgren, 2017; Kostova and Roth, 2002).

Insights from this research paradigm can benefit the GVC research agenda on governance as well as social and economic upgrading. IB research on transferring practices and policies to subsidiaries in different country contexts can be extended to transfer issues beyond the boundaries of the MNE (e.g., Locke, 2013; Sinkovics, Hoque and Sinkovics, 2016). Lucea and Doh (2012) suggest to consider the geographic spread of an MNE's socio-political context in this analysis process and the level of cross-border connectedness of the company's issue network. They define an issue network as 'a set of organizations that share a common interest or concern regarding a specific issue' (ibid., p. 13) and operationalize 'issues' 'as concrete instances or events such as a project, a product, or a firm policy that generate gaps between the expectations of a number of stakeholders and the firm's behaviour' (ibid., p. 12). Additionally, bringing microfoundations into the politicizing MNE perspective can add further value to GVC research, because while MNE structure and strategy shape intra- and interfirm policies, initiatives, and transactions, ultimately it is groups of individuals across a number of organizations who drive and negotiate the content of those policies, initiatives, and transactions as well as how they will be implemented (cf. Boddewyn and Doh, 2011; Doh et al., 2010; Foss, 2009). 


\subsection{CONCLUDING REMARKS}

This chapter sought to provide GVC scholars with an overview of the six main paradigms on the study of the MNE within IB. In the epilogue of his book, Forsgren (2017) outlines an agenda for a seventh type of MNE perspective, which he calls the governing multinational. This approach focuses on the political power of the multinational - more specifically, its ability to negotiate with governments and other institutions. Insights from this emerging body of IB literature can contribute to GVC research on the role of the state in GVCs (cf. Horner and Alford, Chapter 34 this volume). We attempted to flesh out some applications of each theoretical perspective for GVC research. Table 26.1 also includes a number of core readings to provide the interested reader with a starting point for further explorations. Due to space limitations we only sketch out a few of the possible contributions each theoretical perspective can make to GVC research. Each view on the MNE zooms in on a specific perspective and thus can be used as a magnifying glass to shed additional light on specific issues on the larger maps of GVC research.

\section{NOTES}

1. We regard core contributors to a field, IB or GVC respectively, scholars who mostly attend the same conferences (for example European International Business Academy and Academy of International Business for IB scholars, Society for the Advancement of Socio-Economics, European Group for Organizational Studies and the American Association of Geographers for GVC scholars), publish in the same range of journals, and reference more articles from their own field than from other fields. It needs to be noted that GVC researchers tend to publish in a wider range of journals than IB scholars. Nevertheless, there is a recognizable pattern that can be used as a proxy to determine a scholar's main affiliation.

2. Not included here due to space limitations.

\section{REFERENCES}

Abell, P., T. Felin and N. Foss (2008), 'Building micro-foundations for the routines, capabilities, and performance links,' Managerial and Decision Economics, 29 (6), 489-502.

Ambos, T.C. and B. Ambos (2009), 'The impact of distance on knowledge transfer effectiveness in multinational corporations,' Journal of International Management, 15 (1), 1-14.

Ambos, T.C., P.C. Nell and T. Pedersen (2013), 'Combining stocks and flows of knowledge: the effects of intrafunctional and cross-functional complementarity,' Global Strategy Journal, 3 (4), 283-99.

Andersson, U.L.F., A. Gaur, R. Mudambi and M. Persson (2015), 'Unpacking interunit knowledge transfer in multinational enterprises,' Global Strategy Journal, 5 (3), 241-55.

Argote, L. and P. Ingram (2000), 'Knowledge transfer: a basis for competitive advantage in firms,' Organizational Behavior and Human Decision Processes, 82 (1), 150-69.

Bair, J. (2005), 'Global capitalism and commodity chains: looking back, going forward,' Competition and Change, 9 (2), 153-80.

Barney, J.B. and D.N. Clark (2010), Resource-based Theory: Creating and Sustaining Competitive Advantage, Oxford: Oxford University Press.

Bartlett, C.A. and S. Ghoshal (1989), Managing Across Borders: The Transnational Solution, Boston, MA: Harvard Business School Press.

Bilgili, T.V., B.L. Kedia and H. Bilgili (2016), 'Exploring the influence of resource environments on absorptive capacity development: the case of emerging market firms,' Journal of World Business, 51 (5), 700-712.

Boddewyn, J. and J. Doh (2011), 'Global strategy and the collaboration of MNEs, NGOs, and governments for the provisioning of collective goods in emerging markets,' Global Strategy Journal, 1 (3-4), 345-61.

Buckley, P.J. (2002), 'Is the international business research agenda running out of steam?' Journal of International Business Studies, 33 (2), 365-73. 
Buckley, P.J. (2009), 'The impact of the global factory on economic development,' Journal of World Business, 44 (2), 131-43.

Buckley, P.J. (2016), 'The contribution of internalisation theory to international business: new realities and unanswered questions,' Journal of World Business, 51 (1), 74-82.

Buckley, P.J. and M.C. Casson(1991), The Future of the Multinational Enterprise, Basingstoke: Palgrave Macmillan.

Buckley, P.J. and M.C. Casson (2009), 'The internalisation theory of the multinational enterprise: a review of the progress of a research agenda after 30 years,' Journal of International Business Studies, 40 (9), 1563-80.

Buckley, P.J. and P.N. Ghauri (2004), 'Globalisation, economic geography and the strategy of multinational enterprises,' Journal of International Business Studies, 35 (2), 81-98.

Buckley, P.J. and N. Hashai (2004), 'A global system view of firm boundaries,' Journal of International Business Studies, 35 (1), 33-45.

Buckley, P.J. and R. Strange (2015), 'The governance of the global factory: location and control of world economic activity,' Academy of Management Perspectives, 29 (2), 237-49.

Buckley, P.J., J.P. Doh and M.H. Benischke (2017), 'Towards a renaissance in international business research? Big questions, grand challenges, and the future of IB scholarship,' Journal of International Business Studies, $48(9), 1045-64$.

Cantwell, J. and L. Piscitello (2000), 'Accumulating technological competence: its changing impact on corporate diversification and internationalization,' Industrial and Corporate Change, 9 (1), 21-51.

Cantwell, J. and L. Piscitello (2015), 'New competence creation in multinational company subunits: the role of international knowledge,' World Economy, 38 (2), 231-54.

Cantwell, J. and G.D. Santangelo (2000), 'Capitalism, profits and innovation in the new techno-economic paradigm,' Journal of Evolutionary Economics, 10 (1-2), 131-57.

Cantwell, J. and Y.L. Zhang (2011), 'Innovation and location in the multinational firm,' International Journal of Technology Management, 54 (1), 116-32.

Caves, R.E. (2007), Multinational Enterprise and Economic Analysis, Cambridge, UK/New York: Cambridge University Press.

Chandler, A.D. (2013), Strategy and Structure: Chapters in the History of the Industrial Enterprise, Mansfield Centre, CT: Martino Publishing.

Choksy, U.S., N. Sinkovics and R.R. Sinkovics (2017), 'Exploring the relationship between upgrading and capturing profits from GVC participation for disadvantaged suppliers in developing countries,' Canadian Journal of Administrative Sciences, 34 (4), 356-86.

De Marchi, V., E. Di Maria and S. Ponte (2014), 'Multinational firms and the management of global networks: insights from global value chain studies,' in T. Pedersen, M. Venzin, T.M. Devinney and L. Tihanyi (eds), Orchestration of the Global Network Organization, Vol. 27, Bingley, UK: Emerald Group Publishing Ltd, pp. 463-86.

DiMaggio, P.J. and W.W. Powell (2008), The New Institutionalism in Organizational Analysis, Chicago, IL: University of Chicago Press.

Doh, J., B.W. Husted, D. Matten and M. Santoro (2010), 'Ahoy there! Toward greater congruence and synergy between international business and business ethics theory and research,' Business Ethics Quarterly, 20 (3), 481-502.

Engelhoff, W.G. (1988), Organizing the Multinational Enterprise: An Information Processing Perspective, Cambridge, MA: Ballinger Publishing Company.

Felin, T. and N.J. Foss (2005), 'Strategic organization: a field in search of micro-foundations,' Strategic Organization, 3 (4), 441-55.

Felin, T., N.J. Foss and R.E. Ployhart (2015), 'The microfoundations movement in strategy and organization theory,' Academy of Management Annals, 9 (1), 575-632.

Forsgren, M. (ed.) (2017), Theories of the Multinational Firm: A Multidimensional Creature in the Global Economy (3rd edition), Cheltenham, UK and Northampton, MA, USA: Edward Elgar Publishing.

Forsgren, M., U. Holm and J. Johanson (eds) (2005), Managing the Embedded Multinational: A Business Network View, Cheltenham, UK and Northampton, MA, USA: Edward Elgar Publishing.

Foss, N. (2009), 'Alternative research strategies in the knowledge movement: from macro bias to microfoundations and multi-level explanation,' European Management Review, 6 (1), 16-28.

Gereffi, G. and K. Fernandez-Stark (eds) (2016), Global Value Chain Analysis: A Primer (2nd edition), Durham, NC: Duke University Center on Globalization, Governance and Competitiveness (CGGC).

Gereffi, G. and M. Korzeniewicz (eds) (1994), Commodity Chains and Global Capitalism, Westport, CT: Praeger.

Gereffi, G., J. Humphrey and T. Sturgeon (2005), 'The governance of global value chains,' Review of International Political Economy, 12 (1), 78-104.

Ghoshal, S. and N. Nohria (1997), The Differentiated Network Organizing Multinational Corporations for Value Creation, San Francisco, CA: Jossey-Bass Publishers.

Giuliani, E. and C. Macchi (2014), 'Multinational corporations' economic and human rights impacts on developing countries: a review and research agenda,' Cambridge Journal of Economics, 38 (2), 479-517. 
Grunwald, J., K. Flamm and I. Brookings (1985), The Global Factory: Foreign Assembly in International Trade, Washington, DC: Brookings Institution Press.

Hennart, J.F. (1991), 'The transaction cost theory of the multinational enterprise,' in C.N. Pitelis and R. Sugden (eds), The Nature of the Transnational Firm, Abingdon: Routledge, pp. 176-8.

Hoque, S.F., N. Sinkovics and R.R. Sinkovics (2016), 'Supplier strategies to compensate for knowledge asymmetries in buyer-supplier relationships: implications for economic upgrading,' European Journal of International Management, 10 (3), 254-83.

Hoskisson, R.E., M. Wright, I. Filatotchev and M.W. Peng (2013), 'Emerging multinationals from mid-range economies: the influence of institutions and factor markets,' Journal of Management Studies, 50 (7), 1295-321.

Humphrey, J. and H. Schmitz (2002), 'How does insertion in global value chains affect upgrading in industrial clusters?' Regional Studies, 36 (9), 1017-27.

Hymer, S. (1976), The International Operations of National Firms: A Study of Direct Foreign Investment, Cambridge, MA: MIT Press.

Jensen, P.D.Ø. and B. Petersen (2013), 'Global sourcing of services: risk, process, and collaborative architecture,' Global Strategy Journal, 3 (1), 67-87.

Johanson, J. and J.-E. Vahlne (2009), 'The Uppsala internationalization process model revisited: from liability of foreignness to liability of outsidership,' Journal of International Business Studies, 40 (9), 1411-31.

Kogut, B. and U. Zander (1996), 'What firms do? Coordination, identity, and learning,' Organization Science, 7 (5), 502-18.

Kogut, B. and U. Zander (2003), 'Knowledge of the firm and the evolutionary theory of the multinational corporation,' Journal of International Business Studies, 34 (6), 516-29.

Kostova, T. and K. Roth (2002), 'Adoption of an organizational practice by subsidiaries of multinational corporations: institutional and relational effects,' Academy of Management Journal, 45 (1), 215-33.

Kostova, T. and S. Zaheer (1999), 'Organizational legitimacy under conditions of complexity: the case of the multinational enterprise,' Academy of Management Review, 24 (1), 64-81.

Kostova, T., K. Roth and M.T. Dacin (2008), 'Institutional theory in the study of multinational corporations: a critique and new directions,' Academy of Management Review, 33 (4), 994-1006.

Kostova, T., K. Roth and M.T. Dacin (2009), 'Theorizing on MNCs: a promise for institutional theory,' Academy of Management Review, 34 (1), 171-3.

Lakatos, I. (1978), The Methodology of Scientific Research Programmes, Cambridge, UK: Cambridge University Press.

Lee, J. and G. Gereffi (2015), 'Global value chains, rising power firms and economic and social upgrading,' Critical Perspectives on International Business, 11 (3-4), 319-39.

Levin, D.Z. and R. Cross (2004), 'The strength of weak ties you can trust: the mediating role of trust in effective knowledge transfer,' Management Science, 50 (11), 1477-90.

Locke, R.M. (2013), The Promise and Limits of Private Power: Promoting Labor Standards in a Global Economy, New York: Cambridge University Press.

Lorenzen, M. and R. Mudambi (2013), 'Clusters, connectivity and catch-up: Bollywood and Bangalore in the global economy,' Journal of Economic Geography, 13 (3), 501-34.

Lucea, R. and J. Doh (2012), 'International strategy for the nonmarket context: stakeholders, issues, networks, and geography,' Business and Politics, 14 (3), 1-30.

Pfeffer, J.S. and G. Salancik (1978), The External Control of Organizations: A Resource Dependence Perspective, Stanford, CA: Stanford University Press.

Pierce, S.J. (1990), 'Disciplinary work and interdisciplinary areas: sociology and bibliometrics,' in C.L. Borgman (ed.), Scholarly Communication and Bibliometrics, Newbury Park, CA: Sage, pp. 46-58.

Ponte, S. and P. Gibbon (2005), 'Quality standards, conventions and the governance of global value chains,' Economy and Society, 34 (1), 1-31.

Rugman, A.M., A. Verbeke and Q.T.K. Nguyen (2011), 'Fifty years of international business theory and beyond,' Management International Review, 51 (6), 755-86.

Schotter, A. and P.W. Beamish (2013), 'The hassle factor: an explanation for managerial location shunning,' Journal of International Business Studies, 44 (5), 521-44.

Sinkovics, N. and S.F. Hoque (2018), 'The ethical foundations of strategic global value chain governance: tensions and consequences,' paper presented at the Academy of International Business (AIB), Minneapolis.

Sinkovics, N., S.F. Hoque and R.R. Sinkovics (2016), 'Rana Plaza collapse aftermath: are CSR compliance and auditing pressures effective?' Accounting Auditing and Accountability Journal, 29 (4), 617-49.

Sinkovics, N., S.F. Hoque and R.R. Sinkovics (2018a), 'Supplier strategies and routines for capability development: implications for upgrading,' Journal of International Management, 24 (4), 348-68.

Sinkovics, N., R.R. Sinkovics, S.F. Hoque and M. Alford (2018b), 'The use of global value chain/global production network related literature in international business research: investigating the nature and degree of integration,' in J.V. Beaverstock, G. Cook and J. Johns (eds), The Routledge Companion to the Geography of International Business, New York: Routledge, pp. 258-96. 
Sinkovics, N., R.R. Sinkovics, S.F. Hoque and L. Czaban (2015), 'A reconceptualisation of social value creation as social constraint alleviation,' Critical Perspectives on International Business, 11 (3-4), 340-63.

Steiner, E. (1988), Methodology of Theory Building, Sydney: Educology Research Associates.

Sturgeon, T.J. (2009), 'From commodity chains to value chains: interdisciplinary theory building in an age of globalization,' in J. Bair (ed.), Frontiers of Commodity Chain Research, Stanford, CA: Stanford University Press, pp. 110-35.

Teece, D.J. (2007), 'Explicating dynamic capabilities: the nature and microfoundations of (sustainable) enterprise performance,' Strategic Management Journal, 28 (13), 1319-50.

Teece, D.J. (2014), 'A dynamic capabilities-based entrepreneurial theory of the multinational enterprise,' Journal of International Business Studies, 45 (1), 8-37.

Tran, Y., V. Mahnke and B. Ambos (2010), 'The effect of quantity, quality and timing of headquarters-initiated knowledge flows on subsidiary performance,' Management International Review, 50 (4), 493-511.

Yamin, M. (1991), 'A reassessment of Hymer's contribution to the theory of the transnational corporation,' in C. Pitelis and R. Sugden (eds), The Nature of the Transnational Firm, Abingdon: Routledge, pp. 64-80.

Yamin, M. and Y. Kurt (2018), 'Revisiting the Uppsala internationalization model: social network theory and overcoming the liability of outsidership,' International Marketing Review, 35 (1), 2-17.

Yeung, H.W.-C. and N.M. Coe (2015), 'Toward a dynamic theory of global production networks,' Economic Geography, 91 (1), 29-58. 